\title{
Reduksi Hak Warga Negara Dalam RUU Konvergensi Telematika
}

Reduction of The Right of Citizens In the Convergence Telematics Draft"

\author{
Nuning Susilowati \\ Humas Pemda Kediri \\ Karangrejo RT 14/ RW 02, Kecamatan Wungu, Madiun \\ ningsoezh@yahoo.co.id
}

\begin{abstract}
:
In the development of the world of communication, several studies have noted that the reduction of the rights of citizens to communicate. Telematics Convergence rules prepared by the government to regulate convergence is still under discussion. Although there is community involvement but this engagement just because the next piece of this bill is more talk about the consumer. Convergence Bill is also not much to discuss about the public's right to sue the government negligence of duty against the equity of infrastructure. Related to licensing, this bill is very commercial, so worrying about non-commercial institutions such as community or public owned. Telematics Convergence Bill also seemingly favored corporationsd.
\end{abstract}

Keywords: Convergence, Telematics, Citizens 


\begin{abstract}
Abstraksi:
Era konvergensi merupakan salah satu isu hangat yang sedang merebak dalam perkembangan komunikasi, khususnya teknologi informasi komunikasi. Dalam perkembangan dunia komunikasi, beberapa penelitian mencatat telah terjadi reduksi hak-hak warga negara dalam berkomunikasi menjadi hak konsumen.UndangUndang Konvergensi Telematika yang disiapkan pemerintah untuk mengatur konvergensi saat ini masih dalam pembahasan. Hingga saat ini, isi draft RUU Konvergensi Telematika masih mengundang banyak perdebatan. Terlebih terkait dengan pasalpasal RUU yang lebih berbicara tentang hak konsumen daripada hak warga negara. Reduksi hak warga negara atas komunikasi terjadi ketika dalam draft RUU Konvergensi dan Telematika lebih menyebutkan perlindungan terhadap konsumen daripada warga negara. Meskipun ada keterlibatan masyarakat namun keterlibatan ini hanya secuil saja karena selanjutnya RUU ini lebih banyak bicara tentang konsumen. RUU Konvergensi juga tak banyak membahas tentang hak masyarakat untuk menuntut kelalaian pemerintah akan kewajibannya terhadap pemerataan infrastruktur. Terkait pemberian ijin, RUU ini sangat komersil, sehingga mengkhawatirkan lembaga-lembaga non komersial seperti milik komunitas atau publik. RUU Konvergensi Telematika juga terlihat lebih memihak korporasi.
\end{abstract}

Kata Kunci: Konvergensi, Telematika, Warga negara 


\section{PENDAHULUAN}

Perkembangan teknologi komunikasi begitu pesatnya. Saat ini, isu yang sedang menghangat dan banyak diperbincangkan salah satunya adalah pembahasan tentang perkembangan teknologi komunikasi era konvergensi.

Konvergensi secara harfiah adalah dua benda atau lebih bertemu/bersatu di suatu titik; pemusatan pandangan mata ke suatu tempat yang amat dekat. Secara umum, konvergensi adalah penyatuan berbagai layanan dan teknologi komunikasi serta informasi (ICTS - Information and Communication Technology and Services). Konvergensi merupakan era bergabungnya media telekomunikasi tradisional dengan internet. Konvergensi menyebabkan perubahan radikal dalam penanganan, penyediaan, distribusi dan pemrosesan seluruh bentuk informasi baik visual, audio, data dan sebagainya (Preston, 2001). Konvergensi menggeser era analog ke arah digitalisasi. Informasi atau data tidak lagi dalam bentuk analog, tetapi diubah menjadi format digital.

Konvergensi membawa implikasi yang sangat kompleks. Tidak hanya dangkal menampakkan tentang majunya perkembangan teknologi komunikasi, konvergensi juga membawa implikasi pada berbagai bidang, di antaranya komunikasi media, industri, regulasi, juga khalayak.

Konvergensi mengubah hubungan antara teknologi, industri, pasar, gaya hidup dan khalayak. Singkatnya, konvergensi mengubah pola-pola hubungan produksi dan konsumsi, yang 
penggunaannya berdampak serius pada berbagai bidang seperti ekonomi, politik, pendidikan, dan kebudayaan. Perubahan ini ditandai dengan meningkatnya penggunaan media konvergen secara luar biasa. Sebutlah misalnya di Amerika Serikat; dalam laporannya "The Emerging of Digital Economy" pada Mei 1998, US Department of Commerce menyebutkan bahwa dalam tempo 4 tahun saja internet telah mencapai 50 juta pengguna. Angka ini tentu saja fantastis mengingat televisi butuh waktu selama 13 tahun, komputer 16 tahun, radio 38 tahun, dan telepon 74 tahun untuk dapat mencapai jumlah pelanggan yang sama (Mengko, 2001).

Di dunia industri, konvergensi membawa perubahan yang luar biasa. Jika sebelumnya dunia komunikasi didominasi media massa konvensional seperti media cetak dan elektronik, sekarang masyarakat dibawa masuk ke dunia new media dengan hadirnya internet. Jurnalisme online, tv-mobile, jejaring sosial, game online dan radio streaming menjadi contoh bagaimana dunia komunikasi berkembang menjadi tak terbatas dan lebih kompleks. Konvergensi media juga melahirkan aplikasi-aplikasi beragam. Tidak hanya melalui web, transaksi perbankan bahkan juga bisa dilakukan mudah secara mobile.

Kompleksitas era konvergensi dengan berbagai jasa layanan digital tentu saja membawa implikasi bagi regulasi komunikasi. Regulasi komunikasi yang ada sekarang, terkait 
dengan penggunaan teknologi informasi dan komunikasi atau telematika masih bersifat terpisah. Regulasi tersebut diantaranya:

1. Undang-Undang No. 36 Tahun 1999 tentang Telekomunikasi

2. Undang-Undang No. 32 tahun 2002 tentang Penyiaran

3. Undang-Undang No. 11 Tahun 2008 tentang Informasi dan Transaksi Elektronik (ITE)

4. Undang-Undang No. 14 Tahun 2008 tentang Keterbukaan Informasi Publik

Dan tentu saja, undang-undang diatas, pelaksanaannya diikuti oleh sejumlah regulasi seperti peraturan pemerintah, perpres, dan keputusan menteri.

Berkaitan dengan konvergensi, undang-undang diatas dinilai belum mampu menjawab berbagai permasalahan yang dimungkinkan timbul akibat adanya konvergensi. Dalam Rapat Dengar Pendapat (RDP) di Komisi I DPR RI, 1 Februari 2010, Sekjen Kementerian Komunikasi dan Informatika menjelaskan bahwa konvergensi memungkinkan dinikmatinya berbagai macam layanan dalam satu perangkat seperti layanan penyiaran, telekomunikasi, dan Internet. Konvergensi adalah keniscayaan, sudah menjadi kenyataan sehari-hari dan merupakan bagian yang tidak dapat terpisahkan dalam kehidupan berbangsa dan bernegara.

Dalam laporannya tersebut, Sekjen Kemenkominfo juga menjelaskan pengaturan penyiaran dalam era konvergensi, yaitu pemilahan ketentuan yang diatur dalam UU Penyiaran dengan ketentuan yang akan diadopsi dalam UU Konvergensi. Sekjen 
Kemenkominfo menjelaskan UU Penyiaran hanya fokus pada pengaturan penyelenggaraan penyiaran, antara lain:

1. Kegiatan pemancarluasan siaran secara serentak dan bersamaan;

2. Jasa Penyiaran yang difokuskan untuk Audio (Radio) dan Audio Visual (TV);

3. Jaringan (Terestrial, Satelit dan Kabel) yang khusus digunakan dalam menyelenggarakan penyiaran;

4. Penyelenggara penyiaran (badan hukum) yang terbagi kedalam penyelenggara Konten dan penyelenggara jaringan di bidang penyiaran; dan

5. Izin Penyiaran yang terbagi kedalam Izin Penyelenggara konten dan Izin Penyelenggara Jaringan.

Sedangkan UU Konvergensi mengatur hal-hal terkait dengan layanan konvergensi, antara lain:

1. Kegiatan pemancarluasan siaran yang tidak secara serentak dan bersamaan, misalnya video on demand.

2. Jasa tambahan penyiaran (komunikasi data, multimedia atau telekomunikasi lainnya).

3. Jaringan (Terestrial, Satelit dan Kabel) yang digunakan dalam menyelenggarakan layanan konvergensi.

4. Penyelenggara konvergensi (badan hukum) yang bergerak di bidang konten, jaringan, layanan aplikasi, dan fasilitas.

5. Izin penyelenggaraan konvergensi (konten, jaringan, layanan aplikasi, fasilitas). 
Tidak hanya berkaitan dengan UU Penyiaran, perubahan juga akan dilakukan terhadap UU ITE. Ada beberapa hal yang akan diadopsi ke dalam UU Konvergensi.

Yang disampaikan oleh Sekjen Kemenkominfo diatas cukup menjelaskan mengapa pemerintah merasa perlu melahirkan regulasi baru terkait dengan konvergensi. Hingga saat ini regulasi yang dimaksud yaitu UU Konvergensi Telematika masih dalam taraf pembahasan.

Meski masih sebatas draft rencana undang-undang (RUU), nyatanya UU Konvergensi Telematika sudah menimbulkan kontra. Beberapa pihak menilai RUU Konvergensi tidak melindungi hak warga negara, melainkan lebih fokus bicara konsumen. Penelitian SatuDunia (2011) menyimpulkan telah terjadi pereduksian hak warga negara menjadi sekedar hak konsumen. ${ }^{1}$ Firdaus Cahyadi Manajer Knowledge Management SatuDunia saat kunjungan ke COMBINE Resource Institution, 8 Desember 2011 mengatakan meskipun berkali-kali disebutkan kata masyarakat dalam RUU Konvergensi Telematika, namun di batang tubuh RUU ini justru tidak ada satu pasal pun yang mengatur hak warga negara. RUU ini hanya mengatur perlindungan konsumen tapi bukan warga negara. Disebutkan Firdaus, infrastruktur telematika di Indonesia

1 "Mari Cermati RUU Konvergensi Telematika"

http://pelosokdesa.wordpress.com/2012/01/03/mari-cermati-ruu-konvergensitelematikal 
belum merata dan masih terkonsentrasi di Pulau Jawa, Sumatera, dan sebagian Kalimantan, dan Sulawesi. Akibatnya, pelayanan publik melalui internet karena dinilai lebih efisien dan transparan, tak akan tersentuh oleh warga yang tidak terjangkau infrastruktur telematika. Firdaus mencontohkan sistem Seleksi Nasional Masuk Perguruan Tinggi Negeri (SNMPTN) secara online.

Pendapat senada juga dikemukakan oleh Project Officer Media Link, Mujtaba Hamdi. RUU Konvergensi Telematika, dinilai Mujtaba malah memberi jalan korporasi untuk semakin menjadikan informasi sebagai komoditas. Ketimbang melindungi kepentingan dan hak warga negara atas informasi.

\section{HASIL ANALISIS}

\section{A. Telematika di Indonesia}

Prasetya Puspita Saputri mengungkapkan bahwa perkembangan telematika di Indonesia dibagi menjadi tiga tahapan. Pertama adalah periode rintisan yang berlangsung akhir tahun 1970-an sampai dengan akhir tahun 1980-an. Periode kedua disebut pengenalan, rentang waktunya adalah tahun 1990-an, dan yang terakhir adalah periode aplikasi. Periode ketiga ini dimulai tahun $2000 .^{2}$

Berikut ini adalah data tentang perkembangan telematika di Indonesia yang diulas dalam Final Report

\footnotetext{
${ }^{2}$ http://www.prasetyapuspita.info/berita-113-sejarah-perkembangantelematika-di-indonesia.html
} 
Kebijakan Telematika dan Pertarungan Wacana di Era Konvergensi Media milik Satu Dunia.

Dalam buku putih Komunikasi dan Informatika Indonesia tahun 2010 yang diterbitkan oleh Kementerian Komunikasi dan Informatika (Kominfo) disebutkan bahwa sejak tahun 2006 hingga tahun 2008 terdapat peningkatan kepemilikan komputer dalam rumah tangga Indonesia. Pada tahun 2006, kepemilikan komputer di rumah tangga Indonesia hanya 4\%. Pada tahun 2007 meningkat menjadi 6\%. Dan pada tahun 2008 meningkat menjadi 8\%, seperti berikut:

\section{Kepemilikan Komputer dalam rumah tangga}

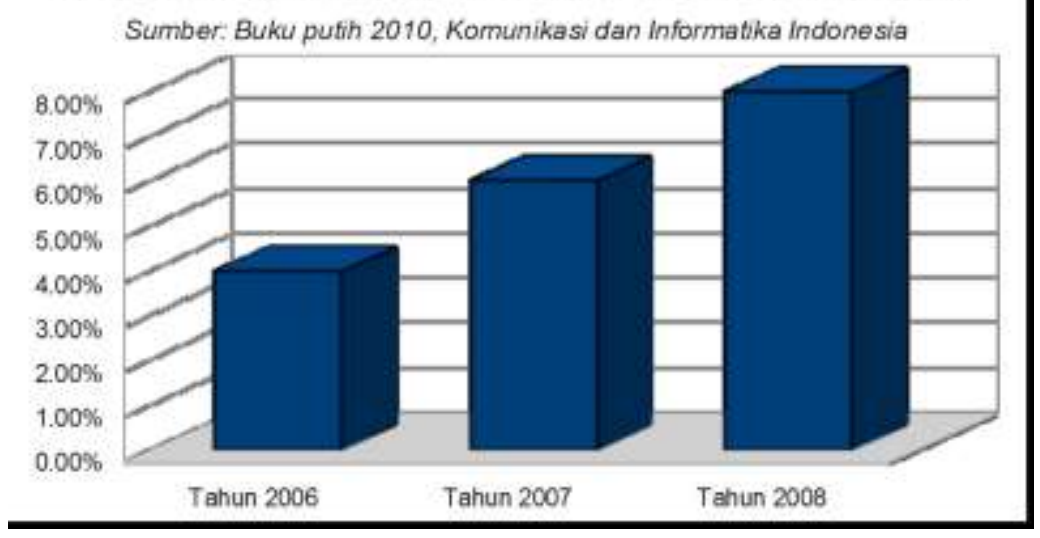


Seiring dengan kenaikan jumlah kepemilikan komputer di Indonesia, pengguna internet di Indonesia pun mengalami banyak peningkatan dalam hal jumlahnya. Tabel berikut menggambarkan prosentase pengguna internet di Indonesia.

\section{Indonesia internet Usage and Population Statistics}

\begin{tabular}{|c|c|c|c|c|c|}
\hline Year & User & Population & Presontase & GDP p.c & Source \\
\hline 2000 & 200000 & 206264595 & $1.00 \%$ & USS 570 & \\
\hline 2007 & 2000000 & 224481720 & $8.90 \%$ & USS 1,916 & \\
\hline 2008 & 2500000 & 237512355 & $10.50 \%$ & USS 2,236 & Af \\
\hline 2009 & 3000000 & 240271522 & $12.50 \%$ & USS 2,329 & IIU \\
\hline 2010 & 3000000 & 242968342 & $12.30 \%$ & USS 2.856 & \\
\hline
\end{tabular}

\section{Sumber: http://www.internetworldstats.com/asia/id.htm}

Menurut Buku Putih "Komunikasi dan Informatika Indonesia" yang diterbitkan oleh Kementerian Komunikasi dan Informatika pada tahun 2010 menyebutkan bahwa pada tahun 2007-2008, akses internet dalam rumah tangga Indonesia mengalami peningkatan pesat. Pada tahun 2007, menurut buku putih tersebut, prosentase keluarga Indonesia yang memiliki akses internet sebesar 5,58 persen. Dan pada tahun 2008 meningkat menjadi 8,56 persen. Sementara menurut Plt Dirjen Postel Muhammad Budi Setiawan, seperti ditulis oleh 
detik.com Juni 2010, mengungkapkan bahwa jumlah pengguna internet di Indonesia telah mencapai angka 45 juta.

Menurut Mastel (Masyarakat Telematika-Indonesia), dari tahun ke tahun penetrasi penggunaan mobile phone terus meningkat. Penggunaan mobile phone yang meninggat ini memungkinkan perluasan akses internet melalui mobile phone.

\begin{tabular}{|c|c|c|c|c|c|}
\hline SERVICES & 2004 & 2005 & 2006 & 2007 & 2008 \\
\hline Fixed Telephones & $8,703,300$ & $8,824,467$ & $8,806,702$ & $8,717,872$ & $8,612,872$ \\
\hline Fixed WirelessPhones & $1,673,081$ & $4,683,363$ & $6,014,031$ & $10,811,635$ & $16,598,550$ \\
\hline Mobile Phones & $30,336,607$ & $46,992,118$ & $63,803,015$ & $93,386,881$ & $124,805,871$ \\
\hline
\end{tabular}

Pengembangan jaringan infrastruktur telekomunikasi di Indonesia masih belum merata ke setiap daerah terpencil. Menurut data Direktorat Jenderal Pos dan Telekomunikasi (2007), dari sekitar 72.000 desa di Indonesia, 38.471 diantaranya belum terjangkau fasilitas telekomunikasi. Sementara pelanggan jaringan telepon di pedesaan hanya sekitar 20,5\% dari total pelanggan dan teledensitas di daerah rural sangat rendah (sekitar 0,2\%). Jika dilihat dari Digital Acces Index (DAI) indeks kemampuan akses dan penggunaan ICT penduduk dalam satu negara. Pada tahun 2002, Indonesia hanya memiliki angka DAI sebesar 0,34 (tergolong medium access) atau berada pada peringkat ke-51 di bawah Mongolia. 
Sementara angka DAI negara tetangga (kecuali Vietnam) jauh lebih tinggi; Singapura $(0,75)$, Malaysia $(0,57)$, Brunei $(0,55)$, Thailand $(0,48)$. Masih rendahnya kualitas SDM, rendahnya pendapatan per kapita penduduk, serta belum meratanya jaringan infrastruktur telekomunikasi itu menunjukkan bahwa tantangan yang dihadapai Indonesia dalam menyikapi persaingan global zaman informasi ini ternyata tidak ringan. Sebab, jika kesenjangan antara rendahnya kualitas SDMpendapatan perkapita Indonesia dengan pesatnya perkembangan ICT di tingkat global dewasa ini dibiarkan saja dan tidak segera diatasi, maka akan berpotensi memperlebar disparitas (kesenjangan) sosial-ekonomi dalam masyarakat. ${ }^{3}$

Pembangunan infrastruktur yang tidak merata ini juga terbaca dari buku putih ICT (Information and Communication Technology) tahun 2010 yang diterbitkan Kementerian Komunikasi dan Informatika. Buku putih itu menyebutkan sebanyak 65,2 persen infrastruktur backbone serat optik terkonsentrasi di Jawa, kemudian diikuti oleh Sumatera (20,31 persen) dan Kalimantan (6,13 persen), sementara pada wilayah Indonesia Timur (Nusa Tenggara, Maluku dan Papua) belum terjangkau infrastruktur ini.

${ }^{3}$ Soekartono. Konvergensi Media dan Masa Depan Bangsa. http://tonz94.files.wordpress.com/2010/11/konvergensi-media-dan-masadepan-bangsa.pdf 


\section{B. Komunikasi sebagai Hak Warga Negara}

Kewarganegaraan merupakan keanggotaan seseorang dalam satuan politik tertentu (secara khusus: negara) yang dengannya membawa hak untuk berpartisipasi dalam kegiatan politik. ${ }^{4}$ Warga negara adalah orang yang mememiliki kewarganegaraan.

Dalam UU No. 12 Tahun 2006 tentang Kewarganegaraan Republik Indonesia pasal 4 yang disebut Warga Negara Indonesia adalah setiap orang yang berdasarkan peraturan perundang-undangan dan/atau berdasarkan perjanjian Pemerintah Republik Indonesia dengan negara lain sebelum Undang-Undang ini berlaku sudah menjadi Warga Negara Indonesia. Setiap orang menjadi warga negara Indonesia bisa karena faktor kelahiran juga faktor lainnya yang diatur dalam UU tersebut.

Dalam konteks warga negara, setiap orang memiliki hak yang sama sebatas dia warga negara Indonesia. Hak-hak tersebut sebagaimana yang tertuang dalam UUD 1945. Setiap warga negara mempunyai hak sesuai UUD 1945, salah satu hak tersebut adalah hak dalam berkomunikasi. Seperti yang disebutkan dalam pasal 28F UUD 1945:

\footnotetext{
${ }^{4}$ http://id.wikipedia.org/wiki/Kewarganegaraan
} 
"Setiap orang berhak untuk berkomunikasi dan memperoleh informasi untuk mengembangkan pribadi dan lingkungan sosialnya, serta berhak untuk mencari, memperoleh, memiliki, menyimpan, mengolah, dan menyampaikan informasi dengan menggunakan segala jenis saluran yang tersedia."

Merujuk pada pasal diatas, sebagai warga negara, individu berhak mendapatkan informasi yang berguna dalam kehidupannya, berhak menyuarakan pendapatnya dalam kehidupan berpolitik, termasuk juga berhak melakukan aktivitas komunikasi, dimana negara dalam hal ini berkewajiban melayani dan melindungi pemenuhan hak-hak tersebut terhadap seluruh warga negara tanpa terkecuali.

Dalam UU no. 39 Tahun 1999 tentang HAM, hak berkomunikasi warga negara tertuang diantaranya dalam;

1. Hak Mengembangkan Diri

Dalam upaya pengembangan dirinya, warga negara berhak atas perlindungan bagi perkembangan dirinya, memperoleh pendidikan, mencerdaskan dirinya, dan meningkatkan kualitas hidup. Setiap individu juga berhak memperoleh manfaat dari ilmu pengetahuan dan teknologi serta berhak berkomunikasi dan memperoleh informasi yang diperlukan untuk pengembangan diri dan lingkungan sosialnya. Hak berkomunikasi ini sampai juga pada hak untuk mencari, memperoleh, memiliki, menyimpan, 
mengolah, dan menyampaikan informasi dengan menggunakan segala jenis sarana yang tersedia.

2. Hak Atas Kebebasan Pribadi

Setiap orang berhak untuk mempunyai, mengeluarkan, dan menyebarluaskan pendapat secara lisan atau tulisan melalui media cetak maupun elektronik.

3. Hak Turut Serta dalam Pemerintahan

Secara politik, setiap individu secara pribadi maupun kelompok berhak mengajukan pendapat, permohonan, pengaduan, dan usulan kepada pemerintah dalam rangka pelaksanaan pemerintahan yang bersih, efektif, dan efisien.

Dalam pemenuhan hak-hak tersebut, tentu saja pemerintah wajib dan bertanggung jawab untuk menghormati, melindungi, menegakkan, dan memajukan hak-hak asasi yang dimaksud.

\section{Komunikasi sebagai Hak Konsumen}

Konsumen menurut Philip Kotler (2000) dalam bukunya Principles of Marketing adalah semua individu dan rumah tangga yang membeli atau memperoleh barang atau jasa untuk dikonsumsi pribadi. Berdasarkan pengertian tersebut, dalam komunikasi, konsumen merupakan mereka yang membeli dan mengonsumsi jasa-jasa layanan bidang 
komunikasi. Kata konsumen memang lebih merujuk pada bidang ekonomi. Dalam hubungannya dengan media, mereka yang menjadi khalayak konsumen adalah orang-orang yang mempunyai kemampuan untuk membeli atau membayar dalam mengakses media. Di sini, khalayak tak lebih dari target pasar.

Karakter khalayak sebagai konsumen atau bagian dari pasar di antaranya adalah dimensi yang meliputinya yang lebih didasarkan pada kriteria-kriteria ekonomi, bukan terhadap hubungan antar individu khalayak. Konsepsi khalayak sebagai konsumen ini memiliki asumsi bahwa identitas khalayak tidaklah penting. Anggapan khalayak sebagai konsumen juga bersifat temporer sesuai dengan karakter produk dan jasa yang ditawarkan melalui pesan media. ${ }^{5}$

Kemampuan untuk menjadi konsumen tentu saja berbanding lurus dengan kemampuan untuk membeli, dan kemampuan membeli tentu saja tak lepas dari tingkat ekonomi. Data Badan Pusat Statistik menyebutkan Perekonomian Indonesia pada tahun 2011 tumbuh sebesar 6,5 persen dibanding tahun 2010. Jika dihubungkan dengan pendapatan per kapita, selama tahun 2011 pendapatan per kapita sudah mencapai Rp 30,8 juta atau sekitar US\$3.542,9. Kenaikannya hampir sama dengan tahun sebelumnya yakni 13,8 persen. Jika

\footnotetext{
${ }^{5}$ Memahami Khalayak Lembaga Penyiaran Publik (Bagian 3) http://wisnumartha14.blogspot.com/2011/07/memahami-khalayak-lembagapenyiaran_16.html
} 
dihitung per bulan, rata-rata pendapatan per kapita penduduk Indonesia sekitar Rp 2,56 juta. ${ }^{6}$ Namun angka-angka tersebut tidak mampu menjawab tentang ekonomi masyarakat Indonesia secara keseluruhan. Satryo Soemantri Brodjonegoro, Anggota Komisi Ilmu Rekayasa Akademi Ilmu Pengetahuan Indonesia, dalam artikelnya yang berjudul "Distorsi Statistik dan Kesenjangan Nasional" mengungkapkan data pertumbuhan ekonomi tidak menggambarkan keadaan riil di masyarakat karena diperoleh secara statistik. Secara rata-rata nasional, jika dihitung berdasarkan statistik, terjadi kenaikan pendapatan nasional dan pertumbuhan ekonomi, namun pada kenyataannya tidak terjadi peningkatan kesejahteraan nasional, bahkan yang terjadi sebenarnya adalah peningkatan kesenjangan nasional. ${ }^{7}$

Asumsi tersebut cukup bisa diterima. Apalagi setelah mencuat di beberapa media tentang perbedaan data kemiskinan di Indonesia. Jumlah orang Miskin di Indonesia berdasarkan data yang diakui oleh Pemerintah per Maret 2011 sebanyak 30,2 juta jiwa, sementara kalau menggunakan data penerima

\footnotetext{
${ }^{6}$ http://inaplas.org/index.php?option=com_content\&view=article \&id=253:pe ndapatan-per-kapita-penuduk-indonesia-naik$138 \&$ catid=5:ekonomi\&Itemid $=6$

${ }^{7}$ http://aipi.or.id/en/news-and-messages/news/84-distorsi-statistik-dankesenjangan-nasional
} 
raskin (Beras Miskin) diatas 70 juta jiwa sedangkan berdasarkan data World Bank masih diatas 100 juta. $^{8}$

Kesenjangan seperti yang dikemukakan diatas ditengarai juga akan terjadi pada daya beli masyarakat. Direktur Eksekutif Perkumpulan Prakarsa, Setyo Budiantoro, mengingatkan dalam sepuluh tahun ke depan dampak kesenjangan pendapatan dan daya beli antara 20 persen warga kelas menengah atas dan 80 persen warga miskin di Indonesia sulit untuk dibendung lagi.

"Selama ini, disparitas warga kaya dan miskin ditutupi oleh rapor pertumbuhan ekonomi yang hanya dinikmati warga kelas menengah ke atas. Namun, pada akhirnya guncangan dari mayoritas warga miskin bakal tak terbendung karena mereka makin kehilangan pendapatan dan daya beli."

Jika ini benar terjadi, tentu saja kesenjangan di bidang komunikasi pun akan mengikuti. Komunikasi tak lebih bahan komoditi bagi golongan tertentu saja. Dan mereka yang hidup dalam kemiskinan akan semakin jauh dari kemajuan. Dan semakin sulit menempati ruang-ruang komunikasi.

\footnotetext{
${ }^{8}$ http://hizbut-tahrir.or.id/2012/03/25/9-alasan-penolakan-kenaikan-hargabbm/

9 “Jangan Abaikan Kesenjangan Ekonomi yang Kian Tajam” http://koranjakarta.com/index.php/detail/view01/91376
} 


\section{Komunikasi, dari Warga Negara ke Konsumen}

Dalam perkembangan dunia komunikasi, beberapa penelitian mencatat telah terjadi reduksi hak-hak warga negara dalam berkomunikasi menjadi konsumen. Pemikiran tentang ruang publik oleh filsuf Jerman Jurgen menjelaskan bagaimana hak warga negara bergeser ke hak konsumen.

Dalam buku-bukunya misalnya The Theories of Communication Action (vol I dan II, 1981) dan The Structural Transformation of The Public Sphere (1962) Habermas banyak mengupas tentang ruang publik dalam dialektikanya dengan negara, publik dan pasar.

Menurut Habermas, dunia mengenal ruang publik pertama kali pada abad kedelapan belas. Masa itu adalah masa kemunculan kapitalisme liberal dan masa bertumbuhnya negara-negara bangsa di Eropa. Kombinasi dari gagasan pencerahan, transformasi pemerintahan dari feodalisme kepada negara-bangsa dan munculnya kapitalisme menciptakan sesuatu yang belum pernah ada sebelumnya dalam sejarah: ruang publik.

Konsep ruang publik muncul dalam pemikiran Habermas tentang harapan akan adanya suatu kondisi atau suatu dunia (ruang) di mana terjadi suatu komunikasi yang bebas dari dominasi, suatu uncoersive communication, di dalam masyarakat. Jurgen Habermas (1997) mengungkapkan bahwa tiap-tiap individu berhak dan memiliki hak yang sama 
untuk masuk ke dalam public shere tersebut. Tiap-tiap orang pada dasarnya sebagai individu yang privat, bukan sebagai orang yang dengan kepentingan bisnis atau politik tertentu. Adanya jaminan bagi mereka untuk berkumpul dan mengekspresikan ide dan gagasan serta pendapat secara bebas tanpa ada perasaan takut atau tekanan dari pihak manapun. Dalam budaya media di era media, tugas utama ruang publik adalah untuk mengidentifikasi masalah-masalah bersama, masalah-masalah publik, dan menyediakan ruang untuk ekspresi.

Dalam pandangannya tentang ruang publik, Habermas melihat media massa secara seimbang dari sisi ekonomi dan politik. Ia tidak menolak bahwa secara ekonomi, media massa merupakan instrumen modal. Namun dari sisi politik, media massa mempunyai fungsi penting dalam membangun public sphere yang dalam sejarah Eropa menjadi sarana penting menuju demokrasi.

Keberadaan media massa tentu saja tak lepas dari pendiriannya sebagai institusi profit oleh kalangan elit tertentu. Dan dalam ekonomi, posisi media terhadap ruang publik kemudian tak lagi menjadi netral. Media tak lagi melihat publik sebagai masyarakat yang harus dijembatani dalam sistem informasi, tetapi dilihat sebagai konsumen yang harus diberdayakan atas produksi-produksi media. 
Dijelaskan oleh Habermas kejadian di Eropa Barat pada abad kesembilan belas dimana pasar telah mengalihkan minat warga negara menjadi konsumen; ketika penguasa menjadi idola dan rakyat penjadi penggemar. Pertumbuhan media massa komersial di era itu dikatakan Habermass telah mengubah publik menjadi konsumen yang pasif. Mereka menjadi tenggelam dalam isu-isu yang bersifat privat, ketimbang isu-isu yang menyangkut untuk kebaikan bersama dan partisipasi demokratis.

Apa yang dikemukan oleh Habermas pada akhirnya banyak terjadi sekarang ini. Hak-hak warga negara akan informasi dan komunikasi telah mengabur. Dalam dunia media kita, warga tak lebih dari konsumen yang menjadi target pasar media. Demi alasan rating untuk mengejar kue iklan atau oplah, banyak tayangan dan isi media yang disajikan lebih berorientasi mencari keuntungan. Tidak hanya itu, industri komunikasi yang beragam melahirkan bentuk komersialitas baru. Tidak hanya berlomba mengejar perangkat teknologi yang modern dan canggih, produsen pun berkompetisi dalam hal konten. Dan disinilah warga semakin terjepit, diantara kepentingan korporasi media, dan elit-elit tertentu, termasuk juga pemerintah. 


\section{E. Draft RUU Konvergensi Telematika}

Jika membaca draft RUU Konvergensi Telematika, kecemasan beberapa pihak akan keberadaan UU Konvergensi Telematika yang lebih memihak korporasi dan pemerintah patut dimaklumi. Ada beberapa poin dalam draft RUU ini yang menimbulkan pertanyaan dan kekhawatirkan kedepan nanti terkait dengan pemenuhan akan hak warga negara.

1. Lebih melihat hak konsumen dari hak warga negara

Bab ketiga pembinaan bagian kedua "Peran Serta Masyarakat" memang berbicara akan eksistensi masyarakat dalam pemanfaat telematika. Misalnya di pasal 7 ayat:

(1) Pemerintah melibatkan peran serta masyarakat dalam penyelenggaraan dan pemanfaatan telematika.

(2) Peran serta masyarakat sebagaimana dimaksud pada ayat (1) dilakukan dalam bentuk penyampaian pemikiran dan pandangan yang berkembang di masyarakat mengenai arah pengembangan telematika dalam rangka penetapan kebijakan, pengaturan, dan pengawasan di bidang telematika.

(3) Ketentuan lebih lanjut mengenai peran serta masyarakat sebagaimana dimaksud pada ayat (2) diatur dengan Peraturan Pemerintah. 
Anehnya, di Bab keenam Ketentuan Sosial Bagian Kesatu disebutkan "Perlindungan Konsumen". Ini meneguhkan bagaimana dalam RUU ini, pengguna dan pemakai jasa telematika lebih dilihat sebagai konsumen daripada sebagai warga negara. Dalam konteks ini konvergensi telematika tak lebih dari komoditas yang mekanismenya akan diserahkan pada pasar. Pembangunan akan terpusat di titik-titik dengan infrastruktur memadai, dalam hal ini daerah-daerah seperti Jawa, Sumatera, Bali, dan Kalimantan masuk dalam daftar karena secara pasar akan lebih menguntungkan. Sementara daerah-daerah Indonesia bagian timur akan semakin tertinggal.

2. Hak akan Infrastruktur

Memang disebutkan pelaksanaan layanan dasar telematika di daerah terpencil (Kewajiban Pelayanan Universal) menjadi tanggung jawab pemerintah, namun tidak disebutkan hak warga negara bila tanggung jawab pemerintah itu lalai atau gagal dilaksanakan. Padahal pemerataan infrastruktur ini merupakan salah satu hak warga negara dalam berkomunikasi. 
3. Komersialisme

Pasal 8 RUU ini memilah penyelenggara telematika menjadi dua yaitu Komersial dan Non-komersial. Menurut RUU ini penyelenggara komersial meliputi penyelenggara fasilitas jaringan telematika, layanan jaringan dan aplikasi telematika, termasuk aplikasi penyebaran konten dan informasi. Terkait perijinan setiap penyelenggara telematika harus mendapatkan ijin dari menteri dan membayar Biaya Hak Penyelenggaraan (BHP) telematika.

4. Berpihak pada korporasi

Pasal 39 menyebutkan bahwa menteri dapat melimpahkan fungsi pengaturan, pengawasan dan pengendalian kepada Badan Regulasi guna menumbuhkembangkan industri telematika. Dengan demikian terbaca indikasi bahwa tujuan dari UU ini adalah menumbuhkembangkan industri telematika. Keterlibatan masyarakat dalam pasal ini disebutkan tapi tidak diungkap secara detail masyarakat yang dimaksud.

Poin-poin tersebut diatas menjadi catatan kekhawatiran akan pemenuhan hak warga negara di era konvergensi. Regulasi yang dibuat oleh pemerintah yang semestinya melindungi warga negara malah lebih difokuskan pada hak konsumen. 


\section{III.KESIMPULAN}

Reduksi hak warga negara atas komunikasi terjadi ketika dalam draft RUU Konvergensi dan Telematika lebih menyebutkan perlindungan terhadap konsumen daripada warga negara. Meskipun ada keterlibatan masyarakat namun keterlibatan ini hanya secuil saja karena selanjutnya RUU ini lebih banyak bicara tentang konsumen. RUU Konvergensi juga tak banyak membahas tentang hak masyarakat untuk menuntut kelalaian pemerintah akan kewajibannya terhadap pemerataan infrastruktur. Terkait pemberian ijin, RUU ini sangat komersil, sehingga mengkhawatirkan lembaga-lembaga non komersial seperti milik komunitas atau publik.

RUU Konvergensi Telematika terlihat lebih memihak korporasi. Tidak boleh dilupakan, bahwa konvergensi media akan melahirkan penyatuan kepemilikan media pada elit tertentu. Pemilik modal lah yang berkuasa terhadap pasokan media. Dalam relasi tiga aktor, negara, pasar, dan publik lagi-lagi publik lah yang akan dirugikan.

Di tengah persaingan dan kompetisi pasar inilah, hak warga negara akan semakin terkikis.. Jika ini terjadi, lagi-lagi mereka yang mempunyai keterbatasan sumber daya akan semakin tertinggal di belakang dalam pemenuhan haknya sebagai warga negara. Terlebih regulasi dari pemerintah lebih memberikan peluang besar pada pasar daripada pada kepentingan warga negara 


\section{Daftar Pusataka}

J. Habermas. 1989. Structural Transformation of Public Sphere. Cambridge: Polity Press

Preston, Paschal. 2001. Reshaping Communications. Thousand Oaks, Calif: Sage

Soekartono. Konvergensi Media dan Masa Depan Bangsa. Diakses dari http://tonz94.files.wordpress.com/2010/ 11/konvergensi-media-dan-masa-depan-bangsa.pdf

Jangan Abaikan Kesenjangan Ekonomi yang Kian Tajam. Dari http://koran-jakarta.com/index.php/detail/view01/91376

Kebijakan Telematika dan Pertarungan Wacana di Era Konvergensi Media. Diakses dari www.satudunia.net

Mari Cermati RUU Konvergensi Telematika. Diakses dari http://pelosokdesa.wordpress.com/2012/01/03/maricermati-ruu-konvergensi-telematika/

Memahami Khalayak Lembaga Penyiaran Publik (Bagian 3). Diakses dari http://wisnumartha14.blogspot.com/2011/07/ memahami-khalayak-lembaga-penyiaran_16.html

http://id.wikipedia.org/wiki/Kewarganegaraan

http://prasetyapuspita.info/berita-113-sejarah-perkembangantelematika-di indonesia.html

http://inaplas.org/index.php?option=com_content\&view $=$ article \&id=253:pendapatan-per-kapita-penuduk-indonesianaik-138\&catid=5:ekonomi\&Itemid $=6$

http://aipi.or.id/en/news-and-messages/news/84-distorsi-statistikdan-kesenjangan-nasional

http://hizbut-tahrir.or.id/2012/03/25/9-alasan-penolakankenaikan-harga-bbm/ 